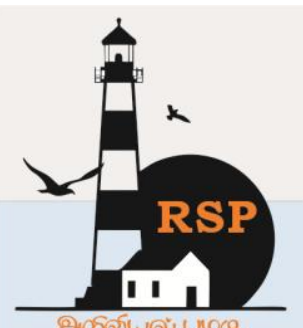

INTERNATIONAL RESEARCH JOURNAL ON ADVANCED SCIENCE HUB

ISSN : $2582-4376$
Open Access

RSP SCIENCE HUB

(The Hub of Research Ideas)

Available online at www.rspsciencehub.com

Special Issue of Second International Conference on Advancements in Research and Development (ICARD 2021)

\title{
Teacher's Attitude towards Information Technology In Relation To Their Gender, Locality and Type of School
}

Priya Sehjal

Research Scholar, Department of Education, CT University, Ludhiana, Punjab India

priyasehjal23@gmail.com

\begin{abstract}
The purpose of conducting this study was to find out the teacher's attitude towards Information Technology (IT) in relation to their Gender, Locality and Type of School. A sample of 100 secondary school teachers working in government and private schools of district Jalandhar was selected through Stratified Random Sampling technique. Attitude Scale towards Information Technology for Teachers (ASTITT-NI) by Nasrin and Islahi (2012) was used for data collection. Mean, SD and t-test were used to compare the attitude towards information technology of male and female, rural and urban, government and private secondary school teachers. The findings of the study revealed that i) there is no significant difference in the attitude of male and female secondary school teachers towards Information Technology ii) Significant difference was found in the attitude of secondary school teachers from rural and urban areas towards information technology. iii) Significant difference was found in the attitude of private and government secondary school teachers towards Information Technology. Private school teachers were found to possess higher level of favourable attitude towards Information technology as compared to government senior secondary school teachers.
\end{abstract}

Keyword: Attitude, Effective teachers, Information Technology (IT), Secondary School teachers

\section{Introduction}

Both teachers and students will be expected to do more in the twenty-first century. Rapid changes occurred in nearly every aspect of society during the 1980s and 1990s. Schools and teachers must deal with a variety of problems, uncertainties, and challenges in such a changing environment. Education goals appear to be more ambiguous and complex than ever before; education tasks are more demanding; public expectations are more diverse; and public accountability is sought more than ever before. Among those who contribute to educational improvement, the teacher is an effective and dominant factor. The effectiveness of teachers is largely determined by their attitude, personality traits, and classroom phenomena such as climate, organization, and management. Various commissions and committees have made recommendations for ways to improve education quality. As a result, teachers are inspired, motivated, and persevere in developing better curriculum, textbooks, and teaching aids. However, all of the efforts will be in vain unless teachers adopt a positive attitude toward educational technology. In this era of information explosion, one of the most basic requirements for education is to prepare students for participation in a networked information society. To meet these new challenges, educational institutions all over the world are being forced to develop better pedagogical methods. The use of technology in our daily lives is very common in today's world. Everyone uses it for a variety of purposes at various locations, such as at home, at work, at a 
business, or elsewhere. Aside from a formal education, an essential qualification in the form of computer literacy, which includes not only literacy but also efficiency and skill, is generally required at almost all levels of employment. Because of the widespread use of technology in all aspects of life, educational institutions must also prepare their students to be technology literate (Kalanada, 2005). The application of information technology in the teaching and learning process is a relatively new phenomenon that has drawn the attention of educational researchers. Teachers and administrators face a challenge in effectively integrating this technology into classroom practises. Several studies claim that incorporating new technologies into the classroom is critical for students to learn how to function in the information age. As Yelland (2000) pointed out, traditional educational environments do not appear to be suitable for preparing learners to function and be productive in today's workplaces. The use of ICT in education can help with motivation and understanding in general. IT integration in education refers to a technology-based teaching and learning process that closely relates to the use of learning technologies in schools in order to familiarize students with technology and help them learn more effectively in a technology-based environment. The importance of IT integration in schools, particularly in the classroom, cannot be overstated. This is because the use of technology in education has a significant impact on pedagogical aspects, as the application of technologies will lead to effective learning with the assistance and support of IT elements and components (Jamieson-Procter et al; 2013). When it comes to effective learning with the use of computers as learning aids, information technology provides assistance and complementary support for both teachers and students (Jeorge et al; 2003).

\section{2. literature review}

Habib (2018) looked at the effectiveness of senior secondary school teachers in terms of their attitudes toward technology. According to the study's findings, the majority of senior secondary school teachers have a favourable or positive attitude toward technology. Teacher effectiveness among senior secondary school teachers is unaffected by gender. The type of school has a significant impact on senior secondary school teachers' effectiveness. Teachers in government senior secondary schools are said to be more successful than those in private schools. Imrana (2017) discovered that a study of secondary school teachers' attitudes toward information and communication technology in relation to their gender and school types. The findings show that secondary school teachers' attitudes toward ICT differ by gender. At the secondary level, female teachers have a more positive attitude toward ICT than male teachers. When compared to private school teachers, government school teachers had a more positive attitude toward using ICT in the classroom. Parveen (2016) investigated secondary school teachers' attitudes toward the use of technology in the classroom. The findings show that attitudes toward the use of technology in the classroom differ significantly between rural and urban teachers, as well as between science and humanities teachers. Chandini (2016) investigated secondary school teachers' attitudes toward the use of computers in the classroom. The findings revealed that there is a large age gap in high school teachers' views toward the use of computers in education. The results have implications for teachers who wish to develop their computer literacy skills. In order for computers to be used in schools, the government must have the necessary facilities. As a result, high school teachers' attitudes toward the use of computers in the classroom will be strengthened.[1-4]

\section{Justification of the study}

We exist in a new environment that is rapidly changing. From practicing to socializing, learning to engaging, IT has an influence on almost every area of our lives. Young people's contact, networking, encouragement, access to information and preparation has all evolved as a result of the modern age. We must understand that young people are an internet community, with access from a multitude of means like laptops, television, and phones. As technology becomes more and more ingrained in our society, we must provide our students with concrete and current interactions that allow them to successfully interact with technology and prepare them for lives. It is widely accepted that when innovations and benefits are backed by technical know-how and sound pedagogy, beginners are motivated and 
purposefully involved in the learning process. Education has benefited from information technologies in a number of respects and at varying levels. Information technology has had an influence on teaching and studying from both a sociological and economic perspective. Information technology such as immersive multimedia, computer conferencing, and the internet are being used by a variety of organizations in developing countries to provide guides. It is important to integrate technical developments into the Indian lecture room in order to keep up with the technological transition in the developing worlds' educational-learning systems.

\section{Objectives}

1. To study the Attitude towards Information Technology of Female and Male Secondary School Teachers.

2. To study the Attitude towards Information Technology of Urban and Rural Secondary School Teachers.

3. To study the Attitude towards Information Technology of Private and Government Secondary School Teachers.

5. Hypothesis of the study

1. There exists no significant difference between Attitude towards Information Technology of Female and Male Secondary School Teachers.

2. There exists no significant difference between Attitude towards Information Technology of Urban and Rural Secondary School Teachers.

3. There exists no significant difference between Attitude towards Information Technology of Private and Government Secondary School Teachers.

\section{Methodology:}

\subsection{Method and Procedure}

The descriptive method of educational analysis for the completion of the present paper is followed in the context of the study.

\section{Sample}

Samples of 100 secondary school teachers were chosen for the present analysis. Out of which 49 were male teachers, 51 were female teachers, 45 were rural teachers, 55 were urban teachers and 48 were government teachers and 52 were private teachers.

\subsection{Tools for data collection:}

Attitude Scale towards Information Technology for Teachers (ASTITT-NI) by Nasrin and Islahi
(2012) was used for data collection in Jalandhar district.

\section{Statistical Techniques}

Mean, SD and t-test has been computed for analyzing the present data.

\section{Result and Discussion:}

The Attitude towards Information Technology scale was achieved on selected sample teachers and $\mathrm{t}$ - value was computed to measure teacher effectiveness of secondary school teachers in relation to their gender, location and type of school. The analysis of information is offered as per the hypothesis.

\section{Hypothesis 1:-}

There exists no significant difference between Attitude towards Information Technology of female and male secondary school teachers.

Table No.1. Attitude towards Information

Technology of female and male secondary school teachers

\begin{tabular}{|c|c|c|c|c|c|}
\hline Gender & $\mathrm{N}$ & Mean & S.D. & $\begin{array}{c}\mathrm{t}- \\
\text { value }\end{array}$ & $\begin{array}{c}\text { Level of } \\
\text { Significance }\end{array}$ \\
\hline female & 51 & 97.74 & 8.59 & 1.045 & $\begin{array}{c}\text { Not } \\
\text { significant } \\
\text { at } 0.01 \& \\
0.05 \text { level }\end{array}$ \\
\hline male & 49 & 105.55 & 9.81 & &
\end{tabular}

The result is 1.045 less than the table value (2.58) at the 0.01 level and (1.96) at the 0.05 level of importance in table no. 1 , the measured t-value. The outcome indicates that there is no significant between female and male secondary school teachers in Attitude towards Information Technology. Hence, at all stages of significance, the null hypothesis is accepted.

\section{Hypothesis 2:-}

There exists no significant difference between Attitude towards Information Technology of urban and rural secondary school teachers.

Table no. 2. Attitude towards Information Technology of urban and rural secondary school teacher

\begin{tabular}{|l|l|l|l|l|c|}
\hline Location & N & Mean & S.D. & $\begin{array}{l}\text { t- } \\
\text { value }\end{array}$ & $\begin{array}{c}\text { Level of } \\
\text { Significance }\end{array}$ \\
\hline Urban & 55 & 242.11 & 34.53 & & $\begin{array}{c}\text { Significant } \\
\text { at 0.01 \& } \\
0.05 \text { level }\end{array}$ \\
\hline Rural & 45 & 211.17 & 32.34 & 4.789 & \\
\hline
\end{tabular}




\section{www.rspsciencehub.com}

The consequence of the measured t- values in table no. 2 is 4.789 higher than the table value (2.58) at the level of 0.01 and (1.96) at the level of importance (0.05). The outcome reveals that there is a significant difference in the Attitude towards Information Technology of urban and rural school teachers. Hence, at all degrees of importance, the null hypothesis is rejected.

\section{Hypothesis 3:}

There exists no significant difference between Attitude towards Information Technology of private and government secondary school teachers.

Table no. 3 Attitude towards Information Technology of private and government secondary school teachers

\begin{tabular}{|c|l|l|l|l|c|}
\hline $\begin{array}{l}\text { Type } \\
\text { of } \\
\text { school }\end{array}$ & N & Mean & S.D. & $\begin{array}{l}\text { t- } \\
\text { value }\end{array}$ & $\begin{array}{c}\text { Level of } \\
\text { Significance }\end{array}$ \\
\hline Private & 52 & 245.23 & 33.56 & 5.175 & $\begin{array}{c}\text { Significant } \\
\text { at } 0.01 \& \\
0.05 \text { level }\end{array}$ \\
\hline Govt. & 48 & 218.46 & 32.87 & & \\
\hline
\end{tabular}

The estimated t- value is 5.175 higher than the table value (2.58) at the 0.01 level and (1.96) at the 0.05 level of importance, resulting in table no. 3 . The outcome indicates that there is a significant difference in the Attitude towards Information Technology of private and government high school teachers. In all degrees of importance; the null hypothesis is rejected.

\section{Conclusion}

With how fast the arena is shifting in terms of growth, procurement, and information and communication technologies, it would need to take urgent steps to keep up if it wishes to remain on track. ICT has a lot of rewards, and it has a positive influence on people's and businesses' dayto-day lives. As a result, ICT development is the best solution for keeping on track, and as a result, ICT development is the way to go in the future. Amazing ICT teaching strategies improve student participation in the classroom while minimizing teaching time. This research looks at how much ICT is used in the classroom and how teachers feel about using it for instructional purposes. The participants applied to the current body of information on the use of ICT for scholarly purposes in developed countries.

\section{Reference}

Volume 03 Issue 03S March 2021

[1].Kalanda, K., (2005) Factors influencing college students' attitude towards technology. Unpublished master's dissertation, University of South Africa. Retrieved from http://uir. unisa.ac.za/bitstream /handle/10500 /1531/ dissertation. pdf?sequence $=1$

[2].Chandini (2016). "Attitude of secondary school teachers towards the use of computers in education". International Journal of Current Research and Modern Education (IJCRME). ISSN (Online): 2455 - 5428 Volume I, Issue II Page No.237

[3].Yelland, N., (2001). Teaching and learning with ICT for numeracy in the early childhood and primary years of schooling. Melbourne. Department of Education, Teaching and Youth Affairs

[4].Jorge, C., Gutterez, E.R., Garce, E, G., Jorge M.C.A., \& Diaz, M.B. (2003). Use of the ICTs and the Perception of E- Learning among university students: A differential perspective according to gender to gender and degree year group. Interactive Educational Multimedia, 7, 13-28. 